Manchester with the same care as the New Zealander!

Again with an eye to the British market, a considerable amount of new work has been carried out on the refrigerated transport of fruit, and it has now been found possible to deliver New Zealand plums in London in excellent condition ; attempts to transport lettuces, tomatoes and passion-fruit, however, have been unsuccessful. An investigation which showed that two varieties of apple-Cox's Orange and Jonathan-travel much better at a carrying temperature of $2^{\circ} \mathrm{F}$. above that hitherto used $\left(33^{\circ}-35^{\circ}\right)$ indicates the enormous scope for detailed research that still remains in the realm of cold storage. It is stated that the present inadequate understanding of the meaning of maturity is one of the greatest obstacles to the progress of refrigerated fruit transport.

In 1932, New Zealand exported about $12,000,000$ pickled pelts-an important by-product of the frozen meat industry. The pelt market is very difficult to accommodate, as different buyers have very different views on what are the most desirable qualities in pelts. Since it is impossible to manufacture economically and at the same time satisfy every buyer, research has been directed along the eminently practical lines of making experimental shipments of pelts and discovering their relative values through reports prepared by the New Zealand Pelt Committee in London. Such research is bound to be costly, but it affords a good illustration of the direct way in which New Zealand is attacking practical problems with the closest co-operation between the buying and selling sides of industry. The programme of the Leather Research Association is largely based on the reports received from the Committee in London.

Active research, in collaboration with the English parasite farm at Farnham Royal, and with the help of the Empire Marketing Board, has been carried out on the elimination of noxious weeds. Particular attention has been paid to the ragwort seed-fly and to the piripiri saw-fly, and the value of both parasites-especially the former-in checking the spread of the weeds has been established. The gorse-seed weevil has been effective in the south only, as the flowering season of gorse in the north does not coincide with the weevil's period of activity. The use of the Buprestid beetle against blackberry has had to be abandoned, as it was beginning to attack apple trees, while the blackberries sometimes survived. New Zealand is thus discovering both the possibilities and pitfalls of this modern method of biological control.

The unglamorous but, for the future of agriculture, fundamentally important task of soil survey is continually being extended. In recent years much valuable information has been obtained on the cause and cure of bush-sickness, a disease closely related to the soil type of the pastures grazed by affected animals. The interesting fact has emerged that this iron-deficiency disease is caused by a lack of available iron in the soil itself, rather than in the vegetation, the animals obtaining an essential part of their iron by ingesting soil along with the grass. The diseases can be controlled by giving limonite licks, but the most complete cure has been obtained with drenches prepared from the soil of a healthy pasture, suggesting that iron deficiency is not the only cause of the ailment. Other cattle ailments have been traced to deficiencies in pastures of magnesium, iodine, calcium and phosphorus.

The work of the Department covers other branches of agriculture, concerned mainly with export produce, as well as geological survey, meteorology and astronomy. In a world abounding in international obstacles to the spread of applied science, it is satisfactory to find that New Zealand and Great Britain at least are co-operating freely to secure the widest application of the results of research to problems affecting the welfare of both. The achievement of that co-operation is perhaps the greatest of the Department's successes.

\section{G. V. JACKS.}

\title{
Scientific Aspects of Cooking
}

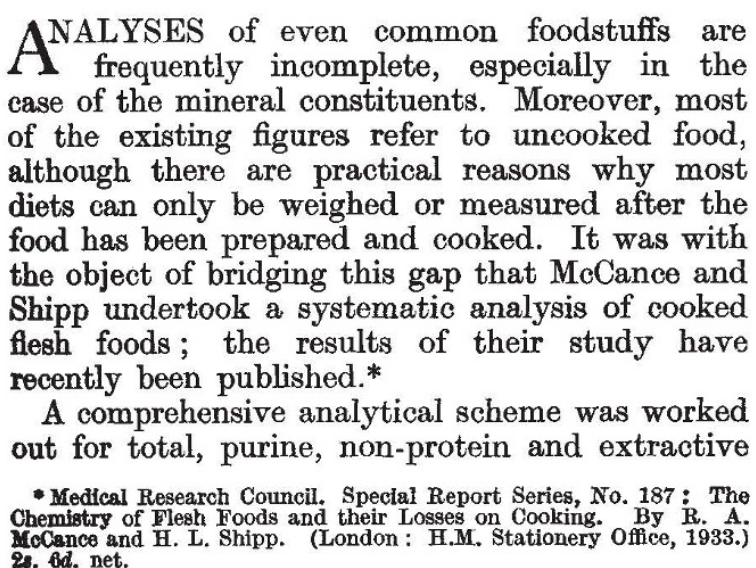
nitrogen, fat, carbohydrate, chloride, total and inorganic phosphorus, sodium, potassium, calcium, magnesium and iron. The chief error was found to lie in the variations of composition of different samples of the same foodstuff : errors of sampling and fortuitous analytical errors were only small. Hence several specimens of each food were analysed whenever possible, but the analyses were not carried out in duplicate. The methods used are described in detail in the report and the analytical figures obtained are set forth in a series of tables and comprise the results of the analyses of 64 samples of fresh fish, 8 of preserved fish, 11 of shellfish, 20 of fresh meat, 8 of preserved meats, 11 of poultry and game, 12 of different animal organs and $a$ few of raw foods. Each figure represents the 
mean of at least two analyses, which were generally made on a mixed sample consisting of several specimens.

Only a few points can be referred to here. In the analytical procedures it is of interest to note that the authors used bromine to deproteinise their aqueous extracts. Examination of the figures obtained showed that the percentage deviation from the mean in the case of protein was 6-10, in the case of fat $30-45$ and in the case of the salts 7-20. The dangerous errors in working with food tables, however, are first the systematic analytical ones and secondly the use of inappropriate tables, for example, those showing raw composition when the food is actually eaten cooked.

All the fish commonly eaten in Great Britain have been analysed: it was found that the white fish have on the whole a uniform composition. The purine content of whitebait was found to be high and only surpassed by that of soft roes and sweet-breads. Smelts, herring and whiting are also rich in purines. Sprats, sardines and whitebait may be a valuable source of calcium, since the bones are small and usually eaten. The winkle is peculiar in containing a very large amount of magnesium. The phosphorus content of foodstuffs depends largely on the amount of edible bone or nuclear material present.

The third section of the report is devoted to an experimental study of the losses brought about by cooking: the losses were determined at intervals after the beginning of cooking, so that the results can be expressed simply in graphical form. Beef and fish were chiefly studied, but there is no reason to suppose that other meats will behave differently. It was found that beef, when fully cooked, loses the same amount of weight, water and salts, whether the cooking is commenced in hot or cold water. When the temperature is raised to $60^{\circ} \mathrm{C}$. all flesh foods shrink, owing to shrinkage of their proteins and the expression of juices. This is the only cause of salt loss when meat is heated in steam or air ; in water, some salts are also lost by diffusion into the water. The extent of the shrinkage of beef, fish, kidney and liver proteins is little affected by raising the temperature from $80^{\circ}$ to $100^{\circ} \mathrm{C}$., but is slightly increased by a further rise to $120^{\circ} \mathrm{C}$. Brain does not shrink below $80^{\circ} \mathrm{C}$.; tripe shrinks when the temperature is raised from $80^{\circ}$ to $100^{\circ} \mathrm{C}$. Fish muscle loses weight in watery solutions below about $p \mathbf{H} \mathbf{5 \cdot 6}$ and gains weight at higher $p \mathrm{H}$. Beef tends to gain weight at all $p \mathrm{H}$ values, especially below $4 \cdot 5$ and above 6.5. Acids and alkalis inhibit the heat shrinkage of muscle proteins. In fish, shrinkage is greatest at $p \mathrm{H} 4 \cdot 0-4 \cdot 5$ at which loss of weight on soaking is greatest; in meat, shrinkage is greatest at about $p \mathrm{H} 6 \cdot 0$. It is suggested that the chief protein in fish has a more acid isoelectric point than that of beef. Shrinkage on heating is not so rapid nor so extreme just after death as it is 40 hours later. In heating by steam, 50 per cent of the water and salts of beef may be lost and a still higher percentage in kidneys. On lowering the $p \mathrm{H}$ of the cooking medium, meat and fish tend to lose more of their cations and less of their anions; fish juices are more alkaline than those of beef, and fish lose relatively more of their anions than meat on cooking in water.

In roasting, the loss of water is nearly all due to evaporation; the loss of salts is small, because when the juices are expressed and the water evaporated, the salts are left on the surface. Frying in deep fat leads to such rapid evaporation of water that the loss of salts is at a minimum. Loss of fat is due to liquefaction of the fat by the heat so that it runs off the meat; shrinkage of the proteins has little influence on the loss of fat.

The authors' experiments have led them to conclude that 'pressure cooking' has no advantage over steaming at $100^{\circ} \mathrm{C}$., however economical it may be in time and fuel. Compared with heating in water, both methods have the advantage that all loss due to leaching out of soluble constituents is avoided. Salt losses in fish are greatly reduced by steaming, but with larger pieces of meat the losses are similar whether the meat is cooked in water or steam. No evidence was found that a pellicle forms on the outside of a joint when cooking is commenced at a high temperature; this procedure can only be supported on grounds of palatability or digestibility. Undercooked meat is probably not more nutritious than overcooked meat; in any event the latter is a more concentrated food, since the greater part of the weight lost in cooking is water.

\section{News and Views}

\section{The Lost Fragrance of Musk}

THE total disappearance within recent years of the scent of musk, Mimutus moschatus Dougl., is one of the most puzzling of plant phenomena. A native of North America, it was introduced into Great Britain from British Columbia in 1826 by the botanist David Douglas. It quickly became a garden favourite, and the yellow, rather insignificant flowers are still a familiar sight in cottage windows. The plant has become naturalised in certain parts of the British Isles and in New Zealand, where it was taken by the early settlers. At the beginning of the present century, the sweet-smelling musk was hawked from door to door in London suburbs. So far as records are available, it appears that the loss of fragrance was first noticed in Britain in 1909, when a well-known nurseryman asked: "Is there such a thing now as a common Musk with the old Musk perfume? Many friends of mine contend that there is not, and I myself am sceptical." Vilmorin, however, in "Les Plantes de Pleine Terre" (fifth edition, 1909), describes the musk as a "petite plante poilue et visqueuse, exhalant une forte odeur musquee, qui se sent a une grande distance", which suggests that 